\title{
Pliensbachian, Early Jurassic radiolarians from Mount Rettenstein in the Northern Calcareous Alps, Austria
}

Tim Cifer, Špela Goričan, Hans-Jürgen Gawlick, and Matthias Auer

Acta Palaeontologica Polonica 65 (1), 2020: 167-207 doi:https://doi.org/10.4202/app.00618.2019

One of the best preserved Early Pliensbachian radiolarian assemblages from the Western Tethys is described from the grey marly limestone exposed at Mount Rettenstein in the Northern Calcareous Alps, south of the Dachstein Massif. Fourty-five genera and 71 species are documented and illustrated here. Four species are newly described: Tozerium filzmoosense Cifer sp. nov., Loupanus pliensbachicus Cifer sp. nov., Thurstonia? robusta Cifer sp. nov., and Ares rettensteinensis Cifer sp. nov. Radiolarian age is in accordance with ammonoid data from the overlying red marly limestone, which was assigned to the upper part of the Lower Pliensbachian. The best equivalent for the radiolarian-bearing lithology is the Dürnberg Formation, characteristic of the open-marine Hallstatt facies zone. Previously published radiolarian data from the Dürnberg Formation were re-evaluated and the originally proposed age assignments revised. At two localities, the published Hettangian-Sinemurian age was emended to the early Early Pliensbachian that is in accordance with the age of radiolarians from Mount Rettenstein. We compared the studied fauna from Mount Rettenstein also with two other rich radiolarian assemblages, one from another locality in the Dürrnberg Formation and one from the Gümüslü Allochthon in Turkey, which were assigned to the late Early Pliensbachian and are somewhat younger than the assemblages studied herein.

Key words: Radiolaria, Polycystina, systematics, stratigraphy, Jurassic, Western Tethys, Eastern Alps, Austria.

Tim Cifer [tim.cifer@zrc-sazu.si] and Špela Goričan [spela@zrc-sazu.si ], Ivan Rakovec Institute of Palaeontology, Research Centre of the Slovenian Academy of Sciences and Arts, Novi trg 2, 1000

Ljubljana, Slovenia. Hans-Jürgen Gawlick [hans-juergen.gawlick@unileoben.ac.at ] and Matthias Auer [Matthias_Auer@gmx.net], Montanuniversität Leoben, Chair of Petroleum Geology, Peter-Tunner-Straße 5, 8700 Leoben, Austria. 
This is an open-access article distributed under the terms of the Creative Commons

Attribution License (for details please see creativecommons.org), which permits unrestricted use, distribution, and reproduction in any medium, provided the original author and source are credited.

FoF Full text $(2,090.4 \mathrm{kB})$ 